\title{
Hospital-Acquired Escherichia coli Infection including OXA- 48 Gene: Case Report
}

\section{OXA-48 Genine Sahip Hastane Kökenli Escherichia coli Enfeksiyonu: Olgu Bildirimi}

\author{
Gokce Kader Arslan' ${ }^{1}$, Selin Ugrakli², Metin Dogan ${ }^{1}$
}

\begin{abstract}
${ }^{1}$ Necmettin Erbakan University, Meram Faculty of Medicine, Medical Microbiology Department, Konya, Turkey

${ }^{2}$ Konya Public Health Management, Public Health Laboratory, Konya, Turkey
\end{abstract}

\section{Öz}

Florada en çok bulunan bakterilerden olduğundan dolayı E. coli'ye karşı direnç gelişimi, özellikle karbapenemaz üreten suşların gelişimi, istenmeyen durumların başında gelmektedir. Hastanemizde iki hastanın klinik örneklerinden OXA-48 direnç genine sahip E. coli izolatları izole edilmiştir. OXA-48 direnç genine sahip $E$. coli izolatlarının izole edildiğinin bildirilmesi ve bu direnç geninin bu mikroorganizmalarda yayılmasının engellenmesi konusunda dikkatlerin çekilmesi amacıyla bu vakaların bildirilmesinin faydalı olacağı düşünülmüştür.

Address correspondence to: Metin Doğan, Anahtar Kelimeler: E.coli, OXA-48, karbapenemaz

Necmettin Erbakan University, Meram Faculty of Medicine, Medical Microbiology Department, Konya, Turkey

e-mail: metin_dogan42@yahoo.com

Geliş Tarihi/Received: 12 January 2021 Kabul Tarihi/Accepted: 5 April 2021

\begin{abstract}
Since it is the most abundant bacteria in the flora, resistance to E. coli, especially the development of carbapenemase-producing strains, is one of the undesired situations. In our hospital, E. coli isolates with OXA-48 resistance gene were isolated from the clinical samples of two patients. It is thoughtThat it would be beneficial to report these cases in order to report the isolation of E. coli isolates with OXA-48 resistance gene and to prevent the spread of this resistance gene in these microorganisms.
\end{abstract}

Key words: E.coli, OXA-48, karbapenemase
Cite this article as: Arslan GK, Ugrakli S, Dogan M. Hospital-Acquired Escherichia coliinfection Including OXA-48 Gene: Case Report. Selcuk Med J 2021;37(2): 176-179
Disclosure: None of the authors has a financial interest in any of the products, devices, or drugs mentioned in this article. The research was products, devices, or not sponsored by an outside organization. All authors have agreed to allow full access to the primary data and to allow the journal to review the data if requested. 


\section{INTRODUCTION}

Members of the Enterobacterales family are bacteria frequently isolated from human flora, particularly gastrointestinal flora. These bacteria can cause various infections. With the development of antibiotic resistance against these bacteria, the fight against infection becomes difficult and these bacteria appear as hospital infection agents(1). Since it is one of the most common bacteria in the flora, the development of resistance against $E$. coli is one of the undesirable situations(2).

Since the 2000s, it has been reported from almost all countries that community-acquired E.coli isolates producing broad-spectrum $\beta$-lactamases (ESBLs) capable of hydrolyzing almost all-lactams except carbapenems have been described. This situation causes an increase in the use of carbapenem in these infections(3). Carbapenemase production, which is among the bacterial resistance mechanisms, is gradually spreading among Gram negative bacteria. The increase of carbepenemase-producing bacteria is one of the feared situations in terms of combating hospital-acquired and community-acquired infections(4).

The emergence and spread of carbapenemase resistance genes among carbapenem-resistant Gram-negative bacteria leads to increased patient morbidity and mortality(5). This situation reduced the treatment efficiency of carbapenem group antibiotics(6). In Enterobacterales, carbapenem hydrolyzing $\beta$-lactamases are class $A \beta$-lactamases (KPC) according to the Ambler classification, Ambler class B $\beta$-lactamases / metallo- $\beta$-lactamases (IMP, VIM and NDM) and class D oxacillinases (OXA-48 and variants).

The first OXA-48-sourced resistance report was made in 2001 from our country in the Klebsiella pneumoniae isolate. Later, reports were made in different bacteria, mostly from our country(7). In our country, OXA 48, one of the resistance genes responsible for carbapenemase production, is seen endemic, while the detection of blaKPC and blaNDM genes is limited to sporadic cases. Plasmid transmission is responsible for the rapid spread of these resistance genes(8).

Besides these; The production of $\beta$-lactamases, efflux pumps, porin loss and mutations that alter the functions and numbers of penicillin binding proteins cause the development of resistance. Various microorganisms producing carbapenemase with genetic origin similar to OXA-48 have been reported in our country(9). Transferring these resistance genes to E.coli, which is one of the most isolated Gram negative in flora, is one of the unwanted cases

Our aim is to draw attention to the prevention of the spread of E.coli isolates with the OXA-48 resistance gene.

\section{CASE}

The first case; 60 -year-old female patient diagnosed with known cervical neoplasia applied to the oncology outpatient clinic for control. E.coli was isolated from the urine culture taken. The patient had a history of hospitalization approximately 1 month ago, and it was learned that he was treated with meropenem $3 \times 1 \mathrm{~g}$ prophylactically. There was no reproduction in the urine cultures taken during this period when the patient was hospitalized. For E.coli isolated during the outpatient clinic control, treatment was not initiated because a colonization was considered. In this case, although it is not considered as an infectious agent, we found it valuable to isolate E.coli with the OXA-48 gene and we wanted to report it.

Second case; 60-year-old male patient with known AML diagnosis applied to hematology outpatient clinic for hidac 2nd consolidation treatment. The patient was admitted to the hematology service because of pain in the chest pain, cough, and sputum complaint. posaconazole $1 \times 300 \mathrm{mg}$ was started when pneumatic areas were seen in chest radiography and thorax tomography of the patient who did not have fever. When the lesion was seen in high resolution computed tomography (HRCT), lung biopsy was performed and the result was reported as necrotizing granulomatous inflammation. The patient's quantiferon test and sputum ARB was negative. Chemotherapy treatment was planned for the patient, and a neutropenic picture developed on the 16th day of chemotherapy and when his fever exceeded $38^{\circ} \mathrm{C}$, meropenem $3 \times 1 \mathrm{~g}$ was started. The patient, whose blood and catheter cultures had no growth, continued to have fever, and the dose was changed to $3 \times 2 \mathrm{~g}$ on the seventh day of meropenem use. E.coli growth was observed as a result of the blood culture that came the next day.And OXA-48 gene was isolated in this isolate. According to the antibiogram results, colistin, tigecycline and amikacin were found to be sensitive. Thereupon, amikacin and colistin were added to the treatment. After 2 days, the patient's CRP levels were decreased and there was no growth in the blood culture samples.

Both cases have a history of hospitalization. Clinical samples taken from the patients were 
evaluated. in routine examinations. Urine samples were incubated at optimum time and temperature by inoculating directly on blood agar and EMB agar. In the first patient, the amount of colonies grown in culture was $10^{5}$ colonies, and the colonies were identified by using the morphological, structural and biochemical properties and Vitek 2 automated system (bioMeriux, France) according to the manufacturer's recommendations. Blood cultures of the second patient were made with an automated system (Becton Dickinson, USA). The identification of the bacteria grown was made with the same system.

The recommendations of the AST card manufacturer, which is compatible with the Vitek 2 automated system, were applied to detect antibiotic susceptibilities. In addition to determining the susceptibility of meropenem, tigecycline and colistin antibiotics, gradient test ( $E$ test) and reference liquid microdilution methods were used. It was interpreted based on clinical breakpoints in the European Susceptibility Committee (EUCAST) to evaluate antibiotic susceptibilities.

In verification of extended spectrum betalactamase $(E S B L)$ producing strains; Gradient test method was used with double disk synergy method. was used with double disk synergy method. Double disc synergy method was tested by placing a disc containing clavulonic acid (amoxicillininclavulonic acid) next to the cephalosporin discs (cefotaxime, ceftazidime and cefepime). Gradient test method used commercial strip tests containing ceftazidime on one end and ceftazidime / clavulonic acid on the other. First strain were evaluated as the ESBL positive, considering the manufacturer's recommendations. The strain in the second case was evaluated as ESBL negative.

The Combined Disc Method (discs containing meropenem and inhibitors; aminophenylboronic acid, phenylboronic acid, dipicolinic acid and cloxacillin) was used for the production of carbapenemase. A high level of temocillin resistance (MIC> $128 \mathrm{mg} / \mathrm{L}$ ) was detected. The resulting synergy and zone diameters were evaluated in line with the manufacturer's recommendations. The susceptibilities of the strains to meropenem, tigecycline and colistin antibiotics were found to be resistant to meropenem, and sensitive to tigecycline and colistin. It was determined that it could phenotypically show OXA 48 feature with the combined disc method.

PCR analysis was performed to determine the OXA-48 resistance genes of these isolates. In order to identify bacterial resistance genes and to see growth curves in real-time PCR, primers were determined; forward primer 5'-TGTTTTTGGTGGCATCGAT-3', reverse primer: 5'-GTAAMRATGCTTGGTTCGC-3' primers were used. DNA amplification was performed using a real-time PCR system (Roche Light Cycler 480 Instrument II, Switzerland).

\section{DISCUSSION}

OXA-48 type carbapenemase producers are probably the most difficult to identify carbapenemase producers and their true prevalence is unclear. The main problem is identifying OXA-48 producers sensitive to cephalosporins and low-level resistance to carbapenems when they do not co-produce ESBL(10). In our country, it has been reported that OXA-48induced carbapenemase has been detected in various microorganisms such as Klebsiella pneumoniae, Acinetobacter baumannii, Pseudomonas aeruginosa (11). Enterobacter cloacae, Providencia rettgeri and C.freundii, especially in hospital-associated infections(7).

Carbapenems are among the most commonly used antimicrobials in the treatment of infections caused by antibiotic-resistant origins, especially in hospitalassociated ones. Carbapenems are increasingly being used to treat infections due to multidrug-resistant Enterobacterales and sometimes empirically. This has a major impact on the emergence of multidrug resistance that can be easily transmitted from one species to another by transferable elements such as plasmids(12). The control of their spread is still possible in hospital settings, and the spread can be prevented by the use of rapid diagnostic techniques, strict implementation of hygiene measures and taking some precautions.

E.coli is a common cause of community-acquired and healthcare-acquired infections and is one of the most common microorganisms isolated in flora. Therefore, the development of antibiotic resistance against these microorganisms draws more attention than the development of resistance against microorganisms that are less isolated in the flora. It is important to identify carbapenemase-producing isolates in clinical microbiology laboratories, both in preventing the spread of these isolates and in the appropriate treatment of the infections they cause. With the reporting of these cases, it was aimed to report that carbapenemase production with the OXA48 gene was detected in two E.coli isolates in our hospital. It was thought that it would be beneficial 
to draw attention to taking necessary precautions in other hospitals.

Conflict of interest: Authors declare that there is no conflict of interest between the authors of the article.

Financial conflict of interest: Authors declare that they did not receive any financial support in this study.

Address correspondence to: Metin Dogan, Necmettin Erbakan University, Meram Faculty of Medicine, Medical Microbiology Department, Konya, Turkey

Phone: 03322237964

e-mail: metin_dogan42@yahoo.com

\section{REFERENCES}

1. Labi AK, Bjerrum S, Enweronu-Laryea CC, et al. High carriage rates of multidrug-resistant Gram-negative bacteria in neonatal intensive care units from Ghana. OFID 2020;7(4):Ofaa-109.

2. Denk A, Tartar A. İdrar kültürlerinden izole edilen toplum kökenli Escherichia coli suşlarında antibiyotik direnci. FÜ Sağ Bil Tıp Derg 2015;29(2):51-5.

3. Nordmann P, Dortet L, Poirel L. Carbapenem resistance in enterobacteriaceae: Here is the storm! Trends Mol Med 2012;18(5):263-72.

4. Kutlu $\mathrm{HH}$, Us $\mathrm{E}$, Tekeli $\mathrm{A}$. Bir üniversite hastanesinde 2010-2014 yılları arasında izole edilen enterobacteriaceae türlerinin karbapenemaz genlerinin araştırılması ve moleküler epidemiyolojisinin belirlenmesi. Mikrobiyol Bul 2018;52(1):112.

5. Patel G, Bonomo R. "Stormy waters ahead": Global emergence of carbapenemases. Front Microbiol 2013;4:48.

6. Nordmann P, Cornaglia G. Carbapenemase-producing enterobacteriaceae: A call for action! Clin Microbiol Infect
2012;18(5):411-2.

7. Carrër A, Poirel L, Yilmaz M, et al. Spread of OXA-48encoding plasmid in Turkey and beyond. Antimicrob Agents Chemother 2010;54(3):1369-73.

8. Kahraman EP, Toptan $\mathrm{H}$, Otlu B, et al. Karbapenemaz üreten klebsiella pneumoniae suslarinda blaoxa-48-benzeri genlerin arastirilmasi. Mikrobiyol Bul 2019:134-43.

9. Papp-Wallace KM, Endimiani A, Taracila MA, et al. Carbapenems: Past, present, and future. Antimicrob Agents Chemother 2011;55(11):4943-60.

10. Nordmann P, Naas T, Poirel L. Global spread of carbapenemase-producing Enterobacteriaceae. Emerg Infect Dis 2011;17(10):1791.

11. Güran M. Karbapenemaz enzimleri: Türkiye'deki durum üzerine bir derleme/carbapenemase enzymes: A review on situation at Turkey. Türkiye Klinikleri Jmed Sci 2016;36(2):98.

12. Khajuria A, Praharaj AK, Kumar M, et al. Emergence of escherichia coli, co-producing NDM-1 and OXA-48 carbapenemases, in urinary isolates, at a tertiary care centre at central India. J Clin Diagn Res 2014;8(6):DC01. 